kard. Stanisław Ryłko

Archiprezbiter Bazyliki Papieskiej

Santa Maria Maggiore, Watykan

DOI: $10.15290 /$ std.2019.05.11

\title{
FORMACJA KATOLIKÓW ŚWIECKICH: WIELKIE WYZWANIE NASZYCH CZASÓW ${ }^{1}$
}

\section{FORMATION OF LAY CATHOLICS: THE GREAT CHALLENGE OF OUR TIME}

The author of the article draws attention to the process of formation of lay Catholics in the Church. He emphasizes the need to understand and respect their identities. Indicates their active presence in society and culture. He emphasizes their ability to discover the beauty and joy of being a Christian.

Key words: secular, identity, formation, faith, Church.

„Przypatrzcie się, bracia, powołaniu waszemu...” (1 Kor 1,26).

Przez wiele lat służyłem trzem kolejnym Następcom św. Piotra, kierując Radą ds. Świeckich. Było to dla mnie szczególne obserwatorium życia Kościoła w naszych czasach: jego trosk i jego nadziei. Laikat jest barometrem, który wiele nam może powiedzieć o stanie Kościoła w danym momencie historycznym.

Chcemy wspólnie słuchać tego, co Duch Święty mówi do Kościoła na tym ważnym wirażu historycznych przemian, jakie ciągle przeżywamy w świecie i w Polsce. Chcemy słuchać Ducha Prawdy, Ducha Pocieszyciela (Parakleta!), który mówi do nas słowami proroctwa Izajasza: „Oto Ja dokonuję rzeczy nowej; pojawia się właśnie. Czyż jej nie poznajecie? Otworzę drogę na pustyni, ścieżyny na pustkowiu..." (Iz 43.19). Dla Kościoła jest rzeczą niezmiernie ważną umieć

Sympozjum: powołanie i misja laikatu w Kościele i świecie, Białystok, 28 maja 2018. 
dostrzegać te „rzeczy nowe”, które za przyczyną Ducha Świętego ciągle dzieją się na naszych oczach: „nowe drogi na pustyni”, „ścieżyny na pustkowiu...”!

W naszych czasach mamy wielką obfitość „proroków nieszczęść” zwiastujących wszelkiego rodzaju klęski, również w wymiarze kościelnym... Brakuje natomiast prawdziwych „proroków nadziei”, dzięki którym - nawet pośród piętrzących się trudności - człowiek odzyskuje wiarę w zwycięstwo prawdy i dobra. Oczywiście, jest niezaprzeczalnym faktem, że dzisiaj rośnie liczba ludzi, którzy żyją tak, jakby Boga nie było; szerzy się „cicha apostazja” ochrzczonych (Jan Paweł II); niepokoi pogłębiająca się obojętność religijna. Ale jest też druga strona medalu: jesteśmy świadkami wielkiego skoku jakościowego w życiu wielu katolików świeckich! Wielu spotyka Chrystusa i daje się zafascynować Jego Ewangelią, nie cofając się przed jej radykalnymi wymaganiami. Wielu katolików odkrywa piękno chrześcijaństwa i wykazuje niezwykły zapał misyjny. W kontekście europejskim są oni mniejszością - to prawda - ale jak mówił Ojciec Święty Benedykt XVI, jest to „mniejszość twórcza” (Arnold Toynbee), decydująca dla przyszłości świata i Kościoła.

W niniejszej refleksji proponuję dotknąć tematu, który w każdej epoce stanowi podstawowe zadanie i wyzwanie dla Kościoła: chodzi o formację katolików świeckich, aby umieli rozpoznać i przyjąć swoje wielkie powołanie i misję w Kościele i świecie. Wielkie usługi na tym polu oddała i w dalszym ciągu oddaje Adhortacja apostolska św. Jana Pawła II Christifideles laici (1989) - owoc Synodu Biskupów (1987) o powołaniu i misji świeckich w Kościele i świecie, w której Papież dokonał doskonałej syntezy nauczania soborowego o laikacie, ubogacając ją równocześnie cennymi doświadczeniami Kościoła posoborowego. Dokument ten bywa nazywany „kartą konstytucyjną” (Magna Charta) laikatu katolickiego. Pomimo upływu lat, w pracy ze świeckimi jest ona niezastąpionym przewodnikiem, jaki winien znajdować się w bibliotece każdego duszpasterza i każdego świeckiego, który na serio traktuje swoje powołanie, stanowiąc przedmiot częstej lektury i medytacji. Dzisiaj lekturę Adhortacji apostolskiej Christifideles laici należy koniecznie uzupełnić dwoma ważnymi dokumentami papieża Franciszka: Adhortacją Evangelii gaudium oraz ostatnią Adhortacją o powołaniu do świętości Gaudete et exsultate.

Adhortacja Christifideles laici ukazuje formację świeckich jako absolutny priorytet duszpasterski: „formacja świeckich powinna się znaleźć wśród zadań priorytetowych diecezji i wejść do programów duszpasterskich tak, aby ku niej zmierzały wszystkie wysiłki wspólnoty (kapłanów, świeckich i osób zakonnych)" (n. 57). Ojciec Święty podkreśla, że „formacja nie jest przywilejem zastrzeżonym tylko dla niektórych ludzi, ale prawem i obowiązkiem wszystkich" (n. 63). Natomiast jej podstawowym celem jest „coraz pełniejsze odkrywanie 
przez nich własnego powołania i coraz większa gotowość do tego, by żyć nim w wypełnianiu własnej misji" (n. 57).

Według Adhortacji Christifideles laici formacja katolików świeckich winna być (por. n. 61):

- integralna: zarówno w wymiarze ludzkim jak i chrześcijańskim;

- spójna: zdolna zapewnić harmonijny i organiczny rozwój mocnych osobowości chrześcijańskich (katolicy z wyboru, z przekonania!);

- kościelna: odbywa się w ramach wspólnoty kościelnej, otwiera na rzeczywistość Kościoła, gdyż bycie chrześcijaninem jest zawsze faktem wspólnotowym (rola wspólnot parafialnych!);

- stała: proces formacji nigdy się nie kończy, przechodząc stopniowo w samowychowanie, kiedy każdy coraz bardziej bierze na siebie odpowiedzialność za swój ludzki i chrześcijański rozwój.

Czym jest w swej istocie formacja katolików świeckich? Polega ona przede wszystkim na permanentnej „inicjacji chrześcijańskiej” ochrzczonych („wtajemniczenie chrześcijańskie”). Ojciec Święty podkreśla z naciskiem:

Nie będzie przesadą stwierdzenie, że celem całej egzystencji świeckiego katolika jest dochodzenie do poznania radykalnej nowości chrześcijańskiej płynącej z chrztu, sakramentu wiary po to, ażeby móc wypełniać swoje życiowe obowiązki, zgodnie z otrzymanym od Boga powołaniem (n. 10).

W chrzcie św. rodzi się nowa tożsamość człowieka, zgodnie ze słowami Apostoła: „Teraz zaś już nie ja żyję, ale żyje we mnie Chrystus” (Ga 2,20). Odkryć decydującą rolę chrztu św. w naszym życiu, to znaczy przeżyć rzeczywiste spotkanie z Chrystusem! Jest to zawsze moment zwrotny w życiu chrześcijanina, gdyż u podstaw bycia chrześcijaninem znajduje się nie tyle jakaś doktryna co żywa Osoba - Jezus Chrystus, który w życiu człowieka otwiera nowy horyzont i przez to nadaje mu decydujący kierunek. Kiedyś, w czasie swojej pierwszej wizyty we Francji, św. Jan Paweł II postawił pytanie, które zaszokowało wielu Francuzów: „Francjo, co zrobiłaś ze swoim Chrztem?...” Nie dawno obchodziliśmy w Polsce kolejną rocznicę Chrztu Polski... Myślę, że podobne pytanie Ojciec Święty stawia nam Polakom dzisiaj: „Co zrobiliście z własnym Chrztem?... Co zrobiłeś z własnym Chrztem?...” Tu decyduje się to, co najważniejsze w naszym życiu!... Przypomniał nam o tym Sobór Watykański II... Pół wieku po zakończeniu Soboru jesteśmy ciągle na początku drogi. Każde pokolenie świeckich i duchownych musi podejmować trud przyswojenia sobie nauczania soborowego o powołaniu i misji świeckich w Kościele i świecie. Jesteśmy wielkimi dłużnikami Soboru - jak mawiał kard. Karol Wojtyła - a jedynym sposobem spłacenia tego długu jest permanentne „uczenie się Soboru” i wprowadzanie go w życie (por. U podstaw odnowy posoborowej). Ojciec Święty Franciszek 
przypomniał niedawno bardzo popularny w okresie soborowym slogan, że w Kościele wybiła „godzina laikatu”, ale zaraz dodał prowokująco, że odnosi się wrażenie, iż ten zegar, który wybił godzinę laikatu, chyba się zatrzymał!? Ta uwaga Papieża daje wiele do myślenia, właśnie w perspektywie formacji laikatu... Zmusza do rachunku sumienia i postawienia sobie wielu pytań: co zaniedbaliśmy w minionych latach, że sprawa powołania i misji świeckich w Kościele i świecie być może również u nas w Polsce - po okresie entuzjazmu, jaki budziła nowość soborowego nauczania - jakoś utknęła i „zegar” wskazujący "godzinę laikatu" się zatrzymał...

Musimy pamiętać, iż kwestia powołania i misji świeckich w Kościele i w świecie to nie jest sprawa „mody”, która przychodzi i mija... Powołanie i misja laikatu wyrasta z eklezjologii soborowej. Według niej Kościół jest tajemnicą komunii misyjnej. Christifideles laici przypomina, iż jest to komunia organiczna, odznaczająca się

współistnieniem wielorakich powołań i stanów, tajemnic, charyzmatów i zadań, które choć różne, są w stosunku do siebie komplementarne. Ta różnorodność i komplementarność sprawia, że każdy świecki pozostaje w relacji do całego ciała i sam wnosi w niego swój własny wkład (n. 20).

Każdy chrześcijanin świecki ma swoją rolę do odegrania i swoje zadanie do wypełnienia zarówno wewnątrz wspólnoty kościelnej (ad intra) jak i na zewnątrz, w stosunku do świata (ad extra). W Kościele nie ma miejsca dla widzów i biernych obserwatorów! Ojciec Święty Franciszek mówił kiedyś o „chrześcijanach balkonowych”, którzy na życie Kościoła patrzą „z wygodnego balkonu”, „na dystans”, unikając bezpośredniego zaangażowania w jego misję. Odpowiedzią na to chrześcijaństwo „balkonowe” jest wizja Kościoła misyjnego, który odważnie wychodzi do świata i jego peryferiów geograficznych i moralnych, i nie boi się ryzyka „ubrudzenia sobie rąk” w służbie Bogu i człowiekowi. Zaś szczególnym „miejscem teologicznym” realizacji powołania świeckich i ich drogą do świętości jest świat, tzn. rodzina, praca zawodowa, życie społeczne, polityczne, struktury samorządowe, kultura, media...Pięknie streścił tę misję starożytny autor Listu do Diogneta: „Czym dusza w ciele, tym w świecie są chrześcijanie...!"

Właśnie ta eklezjologia komunii jest fundamentem formacji wiernych świeckich. Określa ona również kształt i styl wzajemnych odniesień pomiędzy duchownymi i świeckimi w życiu parafii, które w szczególności wykluczają dialektykę walki o władzę, gdyż władza w Kościele to służba. Eklezjologia komunii rodzi potrzebę ciągłej samokontroli zarówno ze strony duchownych jak i świeckich oraz ciągłego dojrzewania. Ze strony duszpasterzy chodzi przede

Por Franciszek, List do kard. Marca Ouellet, Watykan, 19 marca 2016. 
wszystkim o gotowość i umiejętność słuchania świeckich i prowadzenia z nimi autentycznego dialogu, otwarcie na współpracę, umiejętność delegowania zadań, docenianie wkładu, jaki świeccy wnoszą w życie wspólnoty parafialnej, czyli po prostu „bycie z nimi i dla nich...” Ze strony świeckich chodzi o dojrzałą postawę przynależności do wspólnoty parafialnej, przezwyciężenie postawy „oni”, na rzecz postawy solidarnego „my”... Chodzi także o poczucie współodpowiedzialności za życie parafii, gotowość zaangażowania się w dzieła misyjne parafii... Sprawy parafii czy diecezji są „naszą sprawą”, ponieważ Kościół to „my” razem - duchowni i świeccy!... W tym kontekście doniosłą rolę spełniają w naszych parafiach rady parafialne i rady duszpasterskie. Są to doskonałe szkoły współpracy duchowieństwa i świeckich dla dobra wspólnego parafii czy diecezji oraz miejsca, w których współodpowiedzialność świeckich za Kościół znajduje swój konkretny wyraz. Sobór nalega: „pasterze uznawać mają i wspierać godność i odpowiedzialność świeckich w Kościele; mają korzystać chętnie $z$ ich roztropnej rady, powierzać im $z$ ufnością zadania w służbie Kościoła i pozostawiać swobodę oraz pole działania, owszem dodawać im ducha, aby także $z$ własnej inicjatywy przystępowali do pracy" (Lumen gentium, n. 37). We wzajemnych relacjach kapłan winien pamiętać o swym podwójnym statusie wobec świeckich, co zwięźle wyraził św. Augustyn mówiąc: „Dla was jestem Biskupem (Pasterzem), a z wami chrześcijaninem” (przemówienie 340). W życiu kapłana ojcostwo i braterstwo duchowe w stosunku do świeckich muszą iść w parze... Jestem nie tylko „dla nich”, ale jestem też wobec Boga jako chrześcijanin - „jednym z nich”... Rady parafialne i rady duszpasterskie, styl ich pracy oraz ich rozmach misyjny, są ważnym wskaźnikiem żywotności religijnej naszych parafii.

Ojciec Święty Franciszek często mówi o ryzyku klerykalizacji świeckich, co jest winą nie tylko księży, ale i samych świeckich, gdyż skupienie się wyłącznie na sprawach wewnątrzkościelnych jest nieraz łatwiejsze i wygodniejsze, niż pójście w teren, aby głosić Equangelię... Ojciec Święty sprzeciwia się temu zdecydowanie i mówi: „Jest to grzech «na dwie ręce» (duchownych i świeckich)! Musimy przezwyciężyć tę pokusę. Świecki musi pozostać świeckim, człowiekiem ochrzczonym, umocnionym laską tego Sakramentu..." (Discorso, 22 marca 2014).

W procesie formacji świeckich jawią się dzisiaj trzy szczególnie ważne priorytety, które należy mieć na uwadze: a) tożsamość świeckich, b) ich aktywna obecność w społeczeństwie i kulturze (sól ziemi i światłość świata) oraz c) odkrywanie przez nich piękna i radości bycia chrześcijaninem...

A więc przede wszystkim kwestia tożsamości katolików świeckich. Świat współczesny narzuca dzisiaj modele życia, które sieją głęboki zamęt w świadomości ludzi - także ludzi wierzących. Dyktatura relatywizmu, która prawdę zastępuje zbiorem dowolnych opinii, rodzi kulturę pozbawioną trwałych 
punktów odniesienia i wartości („płynne społeczeństwo” według Z. Baumana), a w konsekwencji jest coraz więcej wśród wiernych osobowości kruchych, wewnętrznie podzielonych, niespójnych. Polityczna poprawność staje się dzisiaj absolutnym imperatywem dla wszystkich i - pomimo ciągłych odniesień do tolerancji - nie dopuszcza żadnego sprzeciwu. W dzisiejszym świecie pluralistycznym manifestowanie własnej tożsamości chrześcijańskiej nierzadko jest klasyfikowane jako fundamentalizm lub nawet jako brak tolerancji. Nic więc dziwnego, iż w takim klimacie poczucia chrześcijańskiej tożsamości wielu świeckich katolików uległo osłabieniu, rozcieńczeniu, czy wręcz znajduje się w stanie kryzysu. Rodzi się pytanie: jak pomóc świeckim odkryć fascynującą „nowość życia chrześcijańskiego"? Jak wzbudzić odwagę pójścia pod prąd dyktatowi dominującej dzisiaj kultury laickiej (znak sprzeciwu, sól ziemi!...)? Jak obronić naszą chrześcijańską tożsamość?

Ale na czym w istocie polega poczucie własnej tożsamości? Tożsamość oznacza, iż wiem kim jestem i równocześnie biorę odpowiedzialność za to kim jestem jako chrześcijanin. Otwiera się więc tutaj ważny obszar działania duszpasterskiego zmierzającego do pogłębienia wiary na poziomie świadomości (wiem kim jestem jako chrześcijanin) i na poziomie postaw (biorę odpowiedzialność za to kim jestem) $)^{3}$.

Innymi słowy chodzi tutaj o obudzenie w świeckich odwagi bycia sobą w świecie bez kamuflażu i odkrycie bezcennej wartości swego powołania i misji przeżywanych autentycznie. Trzeba, aby świeccy - zwłaszcza w niektórych środowiskach inteligenckich - wyzwolili się od fałszywych kompleksów niższości wobec świata i odzyskali poczucie słusznej dumy z bycia chrześcijanami i członkami wspólnoty kościelnej oraz dawali odważne świadectwo o swej przynależności do Chrystusa i do Kościoła. Wielkimi mistrzami są tutaj Ojcowie Kościoła. Święty Leon Wielki zachęca: „Chrześcijaninie, poznaj swoją godność!”, a św. Ignacy Antiocheński ostrzega: „Nie wystarczy nazywać się chrześcijaninem, ale trzeba nim być rzeczywiście!..."

Kwestia chrześcijańskiej tożsamości jest w swej istocie kwestią świętości. Można powiedzieć, że świętość to nasze chrześcijańskie być albo nie być... Dlatego na progu trzeciego tysiąclecia św. Jan Paweł II jako pierwszoplanowe zadanie postawil przed Kościołem właśnie świętość, która jest po prostu „wysoką miarą zwyczajnego życia chrześcijańskiego" ${ }^{2}$.

Ojciec Święty wyjaśniał:

Skoro chrzest jest prawdziwym włączeniem w świętość Boga poprzez wszczepienie w Chrystusa i napełnienie Duchem Świętym, to sprzeczna z tym byłaby postawa

3 Por. K. Wojtyła, U źródet odnowy posoborowej, Kraków 1972.

$4 \quad$ Jan Paweł II, Novo millennio ineunte, Watykan 2001, n. 31 
człowieka pogodzonego z własną małością, zadowalającego się minimalistyczną etyką i powierzchowną religijnością. Zadać katechumenowi pytanie: „Czy chcesz przyjąć chrzest?” znaczy postawić na jego drodze radykalizm Kazania na Górze: „Bądźcie więc doskonali, jak doskonały jest Ojciec wasz niebieski” (Mt 5,48) ${ }^{5}$.

Świat potrzebuje chrześcijan, ale chrześcijan autentycznych, którzy żyją pełnią Equangelii, czyli potrzebuje świętych!... Formacja katolików świeckich ma ich zachęcić do walki z własną przeciętnością, otwierając przed nimi fascynujący horyzont świętości. Myśl tę podjął papież Franciszek w swojej ostatniej Adhortacji Gaudete et exsultate. Czytamy w niej: „Dla chrześcijanina jest nie do pomyślenia inna wizja własnej misji na ziemi, niż droga świętości, ponieważ «taka jest wola Boża, wasze uświęcenie» $(1$ Tes 4,3)..." (n. 19) Stąd apel Ojca Świętego: „Nie bój się świętości. Ona nie pozbawi cię mocy, życia i radości...” (n. 32) i dalej:

Nie bój się mierzyć wysoko, pozwól Bogu siebie kochać i wyzwolić. Nie bój się i pozwól się kierować Duchowi Świętemu. Świętość nie uczyni cię mnie ludzkim, ponieważ jest spotkaniem twojej słabości z mocą łaski. W istocie, jak mówił Leon Bloy, w życiu jest tylko jeden powód do smutku (...) czyli ten, że nie jesteśmy święci" (n. 34).

Drugim niezwykle pilnym zadaniem formacji świeckich jest sprawa ich obecności w świecie współczesnym jako prawdziwy „zaczyn ewangeliczny”, „sól ziemi” i „światłość świata”. Jak uruchomić ten wielki potencjał ewangelizacyjny, który w nich jest obecny? Kultura dominująca dzisiaj chce zamknąć wiarę w sferze wyłącznie prywatnej człowieka. Odmawia Bogu prawa do obecności w sprawach tego świata i w konsekwencji stara się zmusić chrześcijan do milczenia, uczynić ich niewidzialnymi w życiu publicznym. Szerzy się dzisiaj zjawisko „nowego anty-chrześcijaństwa” (R. Remond), dziwnego lęku przed chrześcijaństwem. Zasada świeckości państwa zamienia się coraz częściej w agresywny i wrogi chrześcijaństwu laicyzm, który nie toleruje obecności religii w życiu publicznym. I wielu wierzących dzisiaj ulega tej presji i milknie, zostawiając wolną przestrzeń dla tych, którzy krzyczą... W naszym kontekście europejskim, w wielu krajach o prastarej tradycji chrześcijańskiej, katolicy są dziś statystycznie mniejszością i coraz częściej żyją w diasporze. Ale nie to jest naszym głównym problemem. Naszym prawdziwym problemem nie jest bycie mniejszością, lecz nasza przeciętność, małoduszność i przekonanie, iż nie mamy światu nic do zaofiarowania, że jesteśmy niepotrzebni... Sól w pokarmie jest „mniejszością”, a daje smak; zaczyn jest „mniejszością” w cieście, a zakwasza je... Na skutek braku odwagi, na skutek naszej przeciętności i „bylejakości”, my chrześcijanie jesteśmy coraz częściej nieobecni w życiu świata, w jego 
głównych nurtach: stajemy się solą, która utraciła smak, zaczynem, który już nie fermentuje, pochodnią, która zgasła... Chodzi tu o ducha misyjnego... Jak często ulegamy pokusie zamykania się w sprawach wewnątrzkościelnych, tak nam trudno nie raz wyjść z zakrystii na poszukiwanie zagubionych owiec, zabrać głos w sprawach ważnych dla Polski... Nasze kościoły pełne w niedzielę, usypiają naszą czujność i utwierdzają nas w mylnym nieraz przekonaniu, że wszystko jest w porządku. Jednak Chrystus nie przestaje przypominać: „Wy jesteście solą ziemi (...). Wy jesteście światłem świata (...). Tak niech wasze światło jaśnieje przed ludźmi, aby widzieli wasze dobre uczynki i chwalili Ojca waszego, który jest w niebie" (Mt 5,13-10).

Jedną z bardzo niebezpiecznych chorób chrześcijaństwa, zwłaszcza w naszej epoce, jest przeciętność, powierzchowność, obojętność, brak zaangażowania... Chrześcijanie niewidzialni i nieobecni - jako chrześcijanie - w życiu społeczności lokalnych i ojczyzny... Papież Franciszek w swoich homiliach w Domu św. Marty w Watykanie (gdzie rezyduje), wiele miejsca poświęcił analizie dzisiejszych „pozornych chrześcijan”, tworząc ich bogatą typologię: chrześcijanie w słowach a nie w czynie, chrześcijanie salonowi, chrześcijanie „kanapowi”, chrześcijanie „w pantoflach”, chrześcijanie part-time (od święta), chrześcijanie tak, ale „nie za bardzo”, chrześcijanie „balkonowi” (widzowie na dystans), chrześcijanie smutni, zmęczeni i zniechęceni... Konieczne jest jakieś duchowe przebudzenie, rozniecenie we własnym sercu tego zbawiennego niepokoju, aby być rzeczywiście tym, kim jesteśmy z racji chrztu!..

Wiara nie jest sprawą prywatną. Dzisiaj ewangelizować świat to także głosić całą prawdę o człowieku, jego godności i niezbywalnych prawach (prawo do życia od poczęcia do naturalnej śmierci!), jego transcendentnym powołaniu oraz bronić instytucji podstawowych dla osoby ludzkiej, jak małżeństwo i rodzina. W kontekście kryzysu współczesnej kultury, który w swej istocie jest kryzysem antropologii (czyli kryzysem człowieczeństwa!), jest to zadanie niezmiernie ważne. Odrzucając Boga, człowiek przestaje rozumieć samego siebie, kim jest jako osoba ludzka. Sobór Watykański II ostrzegał: „Stworzenie bez Stworzyciela, ginie" (Gaudium et spes, n. 36). Stąd potrzeba szerzenia wśród świeckich znajomości społecznej doktryny Kościoła, która jest częścią integralną ewangelizacji (Jan Paweł II, Centesimus annus, n. 5). Ewangelizować świat, to znaczy przemieniać go w duchu Ewangelii. Trzeba, aby świeccy wchodzili we współczesne areopagi ekonomii, kultury, mediów i polityki z odpowiednią wiedzą fachową i kompetencją, a przede wszystkim z żywą świadomością swojego chrześcijańskiego powołania. W dobie głębokiego kryzysu polityki, jaki przeżywamy, potrzeba nowego pokolenia świeckich katolików w polityce, kompetentnych, o niezaprzeczalnych kwalifikacjach moralnych i fachowych. W naszych czasach jest to doniosły obszar formacji świeckich katolików. 
I wreszcie trzecie pilne zadanie formacji świeckich: uwrażliwianie ich na piękno i radość chrześcijaństwa. Jest to ważny „wspólny mianownik” całej formacji chrześcijańskiej. W dniu inauguracji swego pontyfikatu Benedykt XVI mówił: „Nie ma nic piękniejszego jak dać się dotknąć i zauroczyć Ewangelii i Chrystusowi. Nie ma nic piękniejszego, jak poznać Go i pobudzać innych do przyjaźni z Nim" (24 kwietnia 2005). Zbyt często obraz chrześcijaństwa w oczach naszych współczesnych jest zniekształcony na skutek anty-świadectwa samych chrześcijan. Widzi się w nim nagromadzenie bezdusznych zakazów, które odbierają radość życia. Nic bardziej fałszywego - mówi Papież. Chrześcijaństwo nie jest zniewoleniem człowieka, lecz drogą do pełni życia i pełni wolności. Chrześcijaństwo to na wskroś pozytywny i fascynujący program życiowy i najpełniejsza odpowiedź na najgłębsze tęsknoty ludzkiego serca. Przed wyjazdem na Światowy Dzień Młodzieży w Kolonii (2005), dziennikarz Radia Watykańskiego zapytał Benedykta XVI: „Co przede wszystkim Ojciec Święty chciałby przekazać młodym, którzy z całego świata już przybywają do Kolonii?” Odpowiedź była bardzo zwięzła: „Chciałbym ich przekonać, że bycie chrześcijaninem jest piękne...”. To jest podstawowe zadanie apostolstwa ludzi świeckich: ukazywanie światu piękna Chrystusa, Ewangelii i chrześcijaństwa.

Natomiast Ojciec Święty Franciszek stawia w centrum radość Equangelii. W Adhortacji apostolskiej Evangelii gaudium pisze:
Ewangelizator nie powinien mieć grobowej miny. Odzyskajmy i pogłębmy zapał, „słodką i pełną pociechy radość z ewangelizowania, nawet wtedy gdy trzeba siać płacząc" (...) Oby świat współczesny (...) mógł przyjmować Ewangelię nie od głosicieli smutnych i zniechęconych, niecierpliwych lub bojaźliwych, ale od sług Ewangelii, których życie promieniuje zapałem, od tych, co pierwsi przyjęli Chry- stusową radość..." (n. 10).

Ewangelia jest „Radosną Nowiną” i o tej radości powinniśmy dawać świadectwo!... Chrześcijaństwo zmęczone, smutne i zniechęcone nie jest w stanie porwać świata. Świat dzisiejszy potrzebuje świadectwa radości i entuzjazmu wiary!...

A więc prawda-tożsamość (Jan Paweł II), piękno (Benedykt XVI) i radość (Franciszek) bycia chrześcijaninem! To są te wymiary naszego powołania chrześcijańskiego, które winniśmy ciągle na nowo odkrywać, aby nimi żyć na co dzień. Być chrześcijaninem to Boży dar, który nieskończenie nas przerasta, a równocześnie zadanie i wezwanie, aby do tego daru - z pomocą Łaski Bożej - ciągle dorastać. Bóg otwiera przed każdym z nas fascynujący horyzont przebóstwienia naszej ludzkiej natury: jesteśmy dziećmi Bożymi, nosimy w sobie zaczyn Życia Bożego!... Chrześcijaństwo to droga do pełni człowieczeństwa w Bogu: droga stroma i niełatwa, brama ciasna, przez którą przechodzą tylko 
ci, co są naprawdę zdeterminowani (por. Mt 11,12). To dorastanie do daru bycia chrześcijaninem, jest naszym podstawowym zadaniem...

I ostatnia uwaga... Chrześcijanin świecki to homo Dei - Boży człowiek, człowiek należący do Boga... Chrześcijanin to człowiek, który Boga umieścił w centrum swojego życia... Mogłoby się wydawać, że jest to sprawa tak oczywista, iż nie ma o czym mówić, ale niestety tak nie jest... Nasza Europa coraz bardziej od Boga się oddala, szerzy się „cicha apostazja sytych Europejczyków”, którzy żyją tak, jakby Boga nie było ${ }^{6}$. Prawdziwy problem naszych czasów polega właśnie na kryzysie Boga, na nieobecności Boga w życiu wielu naszych współczesnych. Z niepokojem wsłuchujemy się dzisiaj w słowa Chrystusa: „Czy jednak Syn Człowieczy, gdy przyjdzie, znajdzie wiarę na ziemi?” (Łk 18,8)... A przecież wszystko się zmienia w zależności od tego czy Bóg jest albo Go nie ma! Ukazała się niedawno książka pod prowokującym tytułem: Bóg albo nic (kard. Robert Sarah)... Taka jest alternatywa, jaka staje dzisiaj przed nami!... Do nas należy wybór!... Kryzys Boga, jak wspomnieliśmy, prowadzi nieuchronnie do kryzysu człowieka. Jak nie przypomnieć w tym miejscu dramatycznych słów Papieża Benedykta XVI:

Żyjemy w czasach, w których kryteria człowieczeństwa stały się niepewne (...) Wobec tego wyzwania, my chrześcijanie musimy bronić godności człowieka (...) „Tylko ten, kto zna Boga, zna człowieka”, powiedział kiedyś Romano Guardini. Bez poznania Boga człowiek daje się łatwo manipulować. Wiara w Boga, musi się skonkretyzować w naszym wspólnym zaangażowaniu na rzecz człowieka?

W naszej trosce o formację katolików świeckich popełniamy często podstawowy błąd: zabiegamy o społeczne, kulturowe i polityczne konsekwencje wiary w życiu laikatu (słusznie!), ale zapominamy o fundamencie, zakładając, że ta wiara w naszych wiernych istnieje, co niestety dzisiaj staje się coraz bardziej problematyczne. Kryzys Kościoła w świecie zachodnim, który dociera również do nas w Polsce, polega właśnie na kryzysie wiary wielu ochrzczonych. Bez odnowy wiary, wszelkie reformy strukturalne w Kościele skazane są na niepowodzenie. Formacja świeckich katolików, to przede wszystkim troska Kościoła o ten solidny i trwały fundament wiary, który znalazł wyraz w wyznaniu Piotra w Kafarnaum: „Panie, do kogóż pójdziemy? Ty masz słowa życia wiecznego. A myśmy uwierzyli i poznali, że Ty jesteś Świętym Boga...” (J 6,68).

Słowa kluczowe: świecki, tożsamość, formacja, wiara, Kościół.

6 Jan Paweł II, Ecclesia in Europa, Watykan 2003.

7 Benedykt XVI, Non disperdiamo il dono dell'unità, „L'Osservatore Romano”, 25 września 2011, s. 9. 


\section{Bibliografia:}

1. Benedykt XVI, Non disperdiamo il dono dell'unità, „L'Osservatore Romano”, 25 września 2011.

2. Franciszek, List do kard. Marca Ouellet, Watykan, 19 marca 2016.

3. Jan Paweł II, Ecclesia in Europa, Watykan 2003.

4. Jan Paweł II, Novo millennio ineunte, Watykan 2001.

5. Wojtyła K., U źródeł odnowy posoborowej, Kraków 1972. 